\title{
Mortality prognostic factors associated with SAPS 3 and APACHE II in elderly patients admitted in intensive care unit
}

\author{
Fatores prognósticos associados ao SAPS 3 e APACHE II em pacientes idosos \\ admitidos em unidade de terapia intensiva
}

Marcos Vinícius Ferraz de Lucena ${ }^{1}$, Marcelo Antônio Oliveira Santos-Veloso ${ }^{2}$ (D), Geylson Rodrigo dos Santos Xavier ${ }^{3}$ (D), Inácio Borges Ferreira ${ }^{3}$, Felipe de Castro Moraes ${ }^{3}$ (D), Renata Amorim de Lucena ${ }^{4}$, Letícia Amorim de Lucena ${ }^{5}$, Brivaldo Markman Filho ${ }^{6}$ (D), Sandro Gonçalves de Lima7 (D)

\begin{abstract}
Study design: a descriptive, prospective cohort study. Objectives: identify the risk factors associated with SAPS 3 and APACHE II score to improve mortality prediction in elderly admitted in the intensive care unit (ICU). Methodology: a cohort study with 174 elderly patients admitted in ICU from July 2016 to June 2017. The primary independent variables analyzed were: presence of stress hyperglycemia, the need for invasive mechanical ventilation (IMV), acute renal failure, level of consciousness and use of vasopressors. The outcomes studied were death and hospital discharge. Results: ICU and hospital mortality were $17.8 \%$ and $29.8 \%$, respectively. The multivariate analysis of factors associated with hospital death not contemplated in the obtaining of SAPS 3 demonstrated that IMV, Chronic Obstructive Pulmonary Disease (COPD) and Mean Arterial Pressure (MAP) $<70 \mathrm{mmHg}$ improved the prediction of mortality. The Hosmer-Lemeshow test $(p=0.472)$ and area under ROC curve $=0.80$ (CI95\%:0.731-0.872) confirmed, respectively, an appropriate calibration and acceptable-to-excellent discriminatory power for this model. IMV and COPD were also factors associated with the APACHE II score in prediction of mortality with appropriated calibration $(p=0.471)$ and acceptable-to-excellent discriminatory power (area under ROC curve $=0.80$ [CI95\%:0.730-0.868]). Conclusion: IMV, COPD, and MAP $<70 \mathrm{mmHg}$ were associated with SAPS3 and APACHE II to predict mortality in elderly admitted to ICU.
\end{abstract}

Keywords: Prognostic Factors; Mortality; Elderly; Intensive Care Unit; SAPS 3; APACHE II.

\section{RESUMO}

Modelo de estudo: estudo descritivo, coorte prospectiva. Objetivos: identificar os fatores de risco associados ao escore SAPS 3 e APACHE II para melhorar a predição de mortalidade em idosos internados em unidade de terapia intensiva (UTI). Metodologia: estudo de coorte com 174 idosos internados em UTI no período de julho de 2016 a junho de 2017 . As principais variáveis independentes analisadas foram: presença de hiperglicemia de estresse, necessidade de ventilação mecânica invasiva (VMI), insuficiência renal aguda, nível de consciência e uso de vasopressores. Os desfechos estudados foram morte e alta hospitalar. Resultados: A mortalidade na UTI e hospitalar foi de $17,8 \%$ e $29,8 \%$, respectivamente. A análise multivariada de fatores associados à morte hospitalar não contemplada na obtenção do SAPS 3 demonstrou que a VMI, Doença Pulmonar Obstrutiva Crônica (DPOC) e Pressão Arterial Média (PAM) $<70 \mathrm{mmHg}$ melhoraram a predição de mortalidade. O teste de Hosmer-Lemeshow ( $p=0,472$ ) e a área sob curva ROC =0,80 (IC95\%: 0,731-0,872) confirmaram, respectivamente, calibração adequada e poder discriminatório aceitável a excelente para este modelo. VMI e DPOC também foram fatores associados ao escore APACHE II na predição de mortalidade com calibração adequada $(p=0,471)$ e poder discriminatório aceitável-a-excelente (área sob curva ROC = 0,80 [IC95\%: 0,730-0,868]). Conclusão: VMI, DPOC e PAM <70 mmHg foram associados ao SAPS3 e ao APACHE II para predizer mortalidade em idosos internados em UTI.

Palavras-chave: Fatores Prognósticos; Mortalidade; Idosos; Unidade de Terapia Intensiva; SAPS 3; APACHE II.

1. Programa de Pós-Graduação em Ciências da Saúde. Centro de Ciências da Saúde, Universidade Federal de Pernambuco (UFPE), Recife (PE), Brazil.

2. Programa de Pós-Graduação em Inovação Terapêutica. Centro de Biociências, UFPE, Recife (PE), Brazil.

3. Graduação em Medicina. Departamento de Ciências da Saúde, Centro Universitário Maurício de Nassau (UNINASSAU), Recife (PE), Brazil.

4. Graduação em Medicina. Faculdade Pernambucana de Saúde (FPS), Recife (PE), Brazil.

5. Graduação em Medicina. Faculdade de Ciências Médicas, Universidade de Pernambuco (UPE), Recife (PE), Brazil.

6. Chefe do Serviço de Cardiologia. Hospital das Clínicas da UFPE, Recife (PE), Brazil.

7. Professor adjunto de Cardiologia. Centro de Ciências da Saúde, UFPE, Recife (PE), Brazil.

$\triangle$ Sandro Gonçalves de Lima. Av. Professor Moraes Rego S/N. Centro de Ciências da Saúde, $2^{\circ}$ andar. Cidade Universitária. CEP: 50670-091. Recife (PE), Brazil. sandrolima2002@gmail.com | Recebido: 27/09/2018 | Aprovado: 19/09/2019 


\section{BACKGROUND}

Admission to the Intensive Care Unit (ICU) is associated with high mortality and contributes to higher one-year mortality rates after discharge ${ }^{1}$. Elderly patients are responsible for approximately $42-50 \%$ of the admissions and about $60 \%$ of ICU stays ${ }^{2}$. Clinical outcomes in intensive care are measured using scores that frequently consider the severity of baseline comorbidities ${ }^{3}$. The Acute Physiology and Chronic Health Evaluation II (APACHE II) ${ }^{4}$ and the Simplified Acute Physiology Score 3 (SAPS 3$)^{5}$ scores are widely used in clinical practice to calculate the individual's prognosis as well as to guide therapeutic decisions in ICU patients.

Some independent predictors of death in elderly patients admitted in ICU were previously described in literature: stress hyperglycemia, need for invasive mechanical ventilation (IMV), multiple organs dysfunctions, altered level of consciousness, septic shock, need for vasoactive agents, chronic obstructive pulmonary disease (COPD), and mean arterial pressure (MAP) below $70 \mathrm{mmHg}^{6-11}$. However, the SAPS 3 and APACHE II scores do not consider some of the risk factors already described to affect independently the mortality rates, which might underestimate their predictive values.

This study aimed to recognize risk factors that might be associated with the SAPS 3 and APACHE II to improve the prediction of hospital mortality of elderly patients admitted to ICU.

\section{MATERIALS AND METHODS}

The present study was a prospective cohort study conducted between July 2016 and June 2017 on patients admitted to a public regional ICU in Recife, Pernambuco.

\section{Population}

Patients of both sexes aged 60 or more years admitted and stayed in the ICU for more than 24 hours were eligible for inclusion.
Patients were excluded if diagnosed with terminal cancer under palliative care. Multiple ICU readmissions within a single hospital stay were considered as one single admission.

All patients received standard medical treatment under the direction of the consultant physician.

The primary outcome measures were death or hospital discharge.

\section{Data acquisition}

All data were collected concurrently for consecutive ICU admissions. A structured questionnaire was used to extract data from medical records and guide the history taking of a patient or the family.

Data included sociodemographic information, age, sex, past medical conditions (such as hypertension, diabetes, COPD, chronic kidney or hepatic disease) and lifestyle habits (such as alcohol intake and smoking). The APACHE II and SAPS 3 scores were calculated following the original methodology, using the worst physiologic values in the first ICU day and the first two hours after admission, respectively.

Regarding the Glasgow Coma Scale (GCS), the best results were adopted to define the level of consciousness. Multiple organs failure was defined according to the criteria of Knaus et $\mathrm{al}^{4}$.

All patients were followed until discharge from the hospital or death.

\section{Operational definitions}

Stress hyperglycemia was defined as capillary blood glucose $>180 \mathrm{mg} / \mathrm{dL}^{15}$. Capillary blood glucose was performed using the first drop of blood obtained thought finger puncture with disposable lancets. A measurement was performed every four hours and the higher value in the first 24 hours was chosen.

Acute Kidney Injury (AKI) was defined following the Acute Kidney Injury Network (AKIN) classification: absolute increase within 48 hours in serum creatinine $\geq 0.3 \mathrm{mg} / \mathrm{dL}$; a percentage increase in serum creatinine $\geq 50 \%$ or 1.4 -fold 
from the baseline; or documented oliguria of $<0.5 \mathrm{ml} / \mathrm{kg} / \mathrm{h}$ for at least 6 hours ${ }^{16}$. Creatinine blood samples were processed using the Beckman Coulter AU automated method.

Altered level of consciousness was defined as 8 points or less in the $\mathrm{GCS}^{17}$ in absence of sedative drugs and orotracheal tube.

COPD was defined as the presence of a post-bronchodilator forced expiratory volume in one second (FEV1) $<80 \%$ of the predicted value in combination with a FEV1/forced vital capacity $(\mathrm{FVC})<70 \%$ in a spirometry test or self-reported physician's diagnosis of chronic bronchitis, emphysema, or COPD, associated within use of long-acting muscarinic antagonist (LAMA) and long-acting beta-agonist (LABA) or inhaled corticosteroids $^{18}$.

Intermittent non-invasive blood pressure monitoring was used to acquire diastolic blood pressure (DBP) and systolic blood pressure (SBP). Mean arterial pressure (MAP) was calculated by the formula $(2 \times D B P+S B P) / 3$.

\section{Statistical analysis}

The sample size was calculated based on the purpose of identifying at least five predictors of death. For multiple regression models of dichotomous variables, at least ten outcomes for each predictor might be needed to compound the model with statistical precision ${ }^{12}$. In a model with five dichotomous predictors, as planned for this study, at least 50 outcomes are needed. Expecting a mortality rate of $30 \%{ }^{13,14}$, the minimum sample size is 167 individuals.

We considered for the statistical analyses that the SAPS 3 and APACHE II scores are correlated (Pearson test: $r=0.83 ; p<0.001$ ). Independent analyses were performed to determine which factors might be associated with the scores to improve the prediction of hospital death. The relationship between hospital death and each potential factor associated with the SAPS 3 and APACHE II was determined and adjusted using simple logistic regression models. According to the recommendations of Hosmer-Lemeshow ${ }^{19}$, the factors with a significance level of $p<0.25$ were selected and included in a multivariate logistic regression model. The results were adjusted for two models: one to investigate factors associated with the SAPS 3 and another to examine factors associated with the APACHE II. The selection of factors for each model was performed employing the backward stepwise method, adopting a significance level of $5 \%$. For each adjusted model, the goodness of fit was evaluated using the Hosmer-Lemeshow and the discriminatory power was evaluated using the area under the ROC curve. The Stata 12.1SE software (StataCorp, 4905 Lakeway Drive, College Station, Texas 77845 USA) was used to process the statistical analyses.

\section{Ethical standards}

The study protocol was previously approved by the Institutional Ethics Committee (CAAE: 31993814.6.0000.5208) and respected the Resolution 196/96 of the Brazilian National Health Council, which deals with the guidelines and standards for research involving humans. The investigation was also carried out in accordance with the Declaration of Helsinki. Informed consent was obtained from all patients prior to the inclusion in this study.

\section{RESULTS}

A total of 174 patients was eligible for the study (Figure 1). Mean age was 71.5 years. The ICU and hospital mortality rates were $17.8 \%$ and $29.8 \%$, respectively. The mean of the APACHE II and SAPS 3 scores were 19.1 (16.7 among discharged patients and 24.9 among those in which the outcome was death) and 43.6 (38.7 among discharged patients and 55.0 among those in which the outcome was death), respectively. The mean length of ICU and hospital stay were 7.2 and 32 days, respectively. Population characteristics and prevalence of outcomes are shown in Table 1. 


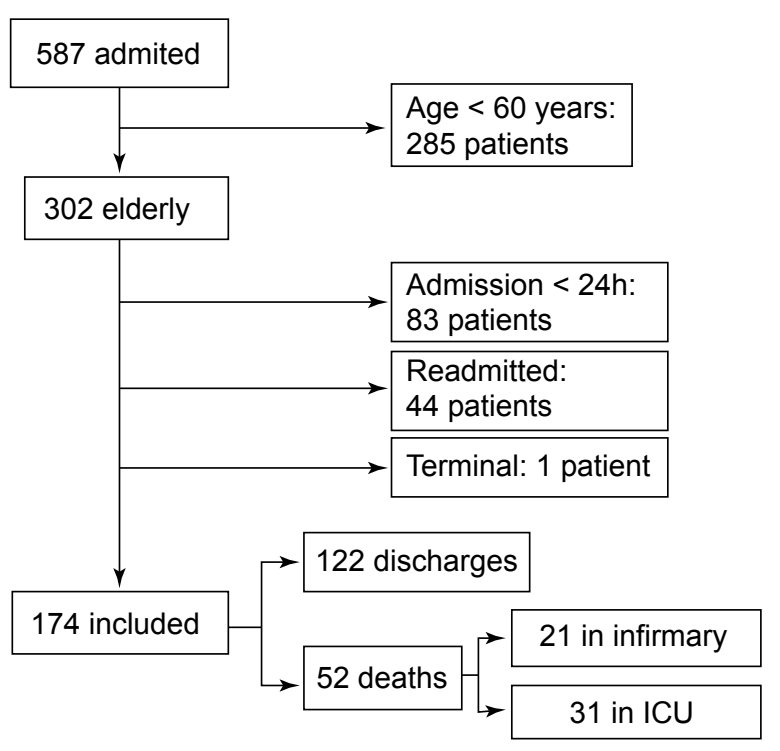

Figure 1: Diagram of inclusion and follow up of the population studied.

Table 1

Summary of sociodemographic, clinical, and laboratorial data of the study population.

\begin{tabular}{|c|c|c|}
\hline \multirow{2}{*}{ Variable } & Sample & Outcome: death \\
\hline & $\mathrm{N}$ & N (\%) \\
\hline \multicolumn{3}{|l|}{ Gender } \\
\hline Male & 79 & $25(31.6 \%)$ \\
\hline Female & 95 & $30(31.5 \%)$ \\
\hline \multicolumn{3}{|l|}{ Ethnicity } \\
\hline White & 85 & $23(27.1 \%)$ \\
\hline Non-White & 89 & $32(35.9 \%)$ \\
\hline \multicolumn{3}{|l|}{ Marital Status } \\
\hline Single & 22 & $5(22.7 \%)$ \\
\hline Married & 87 & $24(27.5 \%)$ \\
\hline Widowed & 52 & $7(13.4 \%)$ \\
\hline Divorced & 13 & $6(46.1 \%)$ \\
\hline \multicolumn{3}{|l|}{ Years of study } \\
\hline 0 & 36 & $12(50.0 \%)$ \\
\hline $1-4$ & 79 & $27(34.1 \%)$ \\
\hline $5-8$ & 34 & $10(29.4 \%)$ \\
\hline $9-11$ & 18 & $4(22.3 \%)$ \\
\hline $12-16$ & 1 & $0(0.0 \%)$ \\
\hline$\geq 17$ & 6 & $1(16.7 \%)$ \\
\hline \multicolumn{3}{|c|}{ Organic system affected } \\
\hline Neuro & 13 & $6(46.1 \%)$ \\
\hline Cardio & 82 & $16(19.5 \%$ \\
\hline
\end{tabular}

Table 1 (Continuation)

\begin{tabular}{|c|c|c|}
\hline \multirow{2}{*}{ Variable } & Sample & Outcome: death \\
\hline & $\mathrm{N}$ & N (\%) \\
\hline Pneumo & 32 & $13(40.6 \%)$ \\
\hline Gastro & 25 & $11(44 \%)$ \\
\hline Nefro/Metab & 20 & $9(45 \%)$ \\
\hline \multicolumn{3}{|l|}{ Reason of admission } \\
\hline High-risk post-op & 62 & $11(17.7 \%)$ \\
\hline ARF & 25 & $9(36 \%)$ \\
\hline ALC & 13 & $7(53.8 \%)$ \\
\hline Shock & 15 & $9(60 \%)$ \\
\hline ACS & 16 & $1(6.2 \%)$ \\
\hline Arrhythmias & 4 & $2(50 \%)$ \\
\hline Other & 23 & $8(34.7 \%)$ \\
\hline IMV & 74 & $41(55.4 \%)$ \\
\hline Length of IMV (days) & $5.9 \pm 5.5$ & $8.1 \pm 8.5$ \\
\hline TQT & 15 & $9(60 \%)$ \\
\hline Length of TQT (days) & $\begin{array}{r}47 \pm \\
50.3\end{array}$ & $31.2 \pm 22.5$ \\
\hline Hypertension & 139 & $40(28.7 \%)$ \\
\hline DM & 87 & $25(28.7 \%)$ \\
\hline COPD & 7 & $4(57.1 \%)$ \\
\hline Smoking & 36 & $10(27.7 \%)$ \\
\hline Alcoholism & 19 & $6(31.5 \%)$ \\
\hline Chronic Hepatic Disease & 8 & $5(62.5 \%)$ \\
\hline \multicolumn{3}{|l|}{ Kidney Injury } \\
\hline Acute & 45 & $25(55.5 \%)$ \\
\hline Chronic & 31 & $13(41.9 \%)$ \\
\hline Cancer & 25 & $8(32 \%)$ \\
\hline Infection & 77 & $34(44.1 \%)$ \\
\hline Vasoactive agent & 79 & $35(44.3 \%)$ \\
\hline \multicolumn{3}{|l|}{ MAP $(\mathrm{mmHg})$} \\
\hline$<70$ & 31 & $23(74.1 \%)$ \\
\hline $70-109$ & 66 & $14(21.2 \%)$ \\
\hline$\geq 110$ & 77 & $18(23.3 \%)$ \\
\hline \multicolumn{3}{|l|}{ Respiratory rate } \\
\hline$<12$ & 1 & $0(0 \%)$ \\
\hline $12-24$ & 110 & $30(27.2 \%)$ \\
\hline$\geq 25$ & 63 & 25 (39.6\%) \\
\hline \multicolumn{3}{|l|}{ Cardiac rate } \\
\hline$<120$ & 146 & $43(29.4 \%)$ \\
\hline $120-159$ & 27 & $12(44.4 \%)$ \\
\hline$\geq 160$ & 1 & $0(0 \%)$ \\
\hline
\end{tabular}


Table 1 (Continuation)

\begin{tabular}{|c|c|c|}
\hline \multirow{2}{*}{ Variable } & Sample & Outcome: death \\
\hline & $\mathrm{N}$ & $N(\%)$ \\
\hline \multicolumn{3}{|c|}{ Temperature $\left({ }^{\circ} \mathrm{C}\right)$} \\
\hline$<34,5$ & 50 & $19(38 \%)$ \\
\hline$\geq 34,5$ & 124 & $36(29.1 \%)$ \\
\hline \multicolumn{3}{|c|}{ Hematocrit (\%) } \\
\hline$<30$ & 87 & $34(39.1 \%)$ \\
\hline $30-45$ & 84 & $19(22.6 \%)$ \\
\hline$\geq 46$ & 3 & $2(66.6 \%)$ \\
\hline \multicolumn{3}{|c|}{ Platelets (in thousands) } \\
\hline$<20$ & 2 & $2(100 \%)$ \\
\hline $20-49$ & 3 & $1(33.3 \%)$ \\
\hline $50-99$ & 17 & $8(47.1 \%)$ \\
\hline \multicolumn{3}{|c|}{ Total Bilirubin (md/dL) } \\
\hline$\geq 100$ & 152 & $44(28.9 \%)$ \\
\hline$<2$ & 159 & $45(28.3 \%)$ \\
\hline $2-5.9$ & 10 & $7(70 \%)$ \\
\hline$\geq 6$ & 5 & $3(60 \%)$ \\
\hline \multicolumn{3}{|l|}{ Leucocytes } \\
\hline$<15,000$ & 112 & $31(27.6 \%)$ \\
\hline$\geq 15,000$ & 62 & $24(38.7 \%)$ \\
\hline \multicolumn{3}{|l|}{$\mathrm{pH}$} \\
\hline$\leq 7,25$ & 29 & $16(55.1 \%)$ \\
\hline$>7,25$ & 145 & $39(26.8 \%)$ \\
\hline
\end{tabular}

$\mathrm{ARF}=$ acute respiratory failure; $\mathrm{ALC}=$ altered level of consciousness ACS = acute coronary syndrome. IMV = invasive mechanical ventilation; $\mathrm{TQT}=$ tracheostomy; $\mathrm{DM}=$ diabetes mellitus; $\mathrm{COPD}=$ chronic obstructive pulmonary disease; MAP = mean arterial pressure.

According to the multivariate analyses (Table 2), IMV, OCPD and MAP $<70 \mathrm{mmHg}$ were associated with the SAPS 3 to predict hospital mortality. The Hosmer-Lemeshow test $(p=0.472)$ and the area under ROC curve $(0.80$ [CI95\%:0.731-0.872]). Figure 2 confirms appropriate calibration and acceptable discriminatory power for the model composed of those four variables.

The results of the univariate and multivariate analyses of factors associated with hospital death not included in the APACHE II score are shown in Table 2. According to the multivariate analyses IMV and OCPD were associated with the APACHE II to predict hospital mortality. The Hosmer-Lemeshow test $(p=0.471)$ and the area under ROC curve (0.80 [CI95\%:0.730-0.868]).
Figure 3 confirms appropriate calibration and acceptable discriminatory power for the model composed of those three variables.

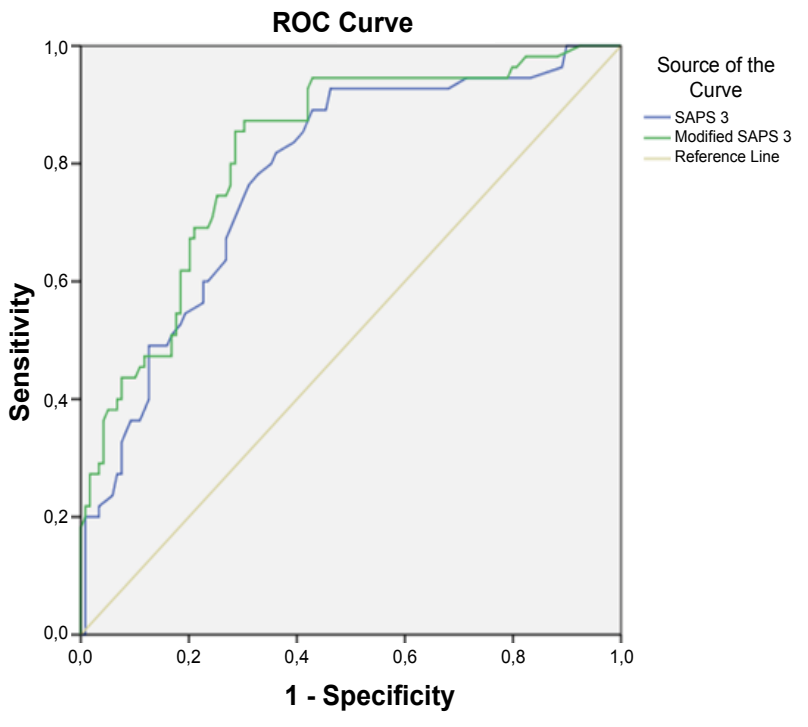

Figure 2: Receiver Operating Characteristics (ROC) curve for SAPS3.

Blue line - ROC curve for isolated SAPS 3 score (AUC 0.77 [CI95\%: 0.706-0.852]). Green line - ROC curve for the modified SAPS 3 score including COPD, IMV, and MAP $<70 \mathrm{mmHg}$ (AUC 0.80 [CI95\%:0.731-0.872]).

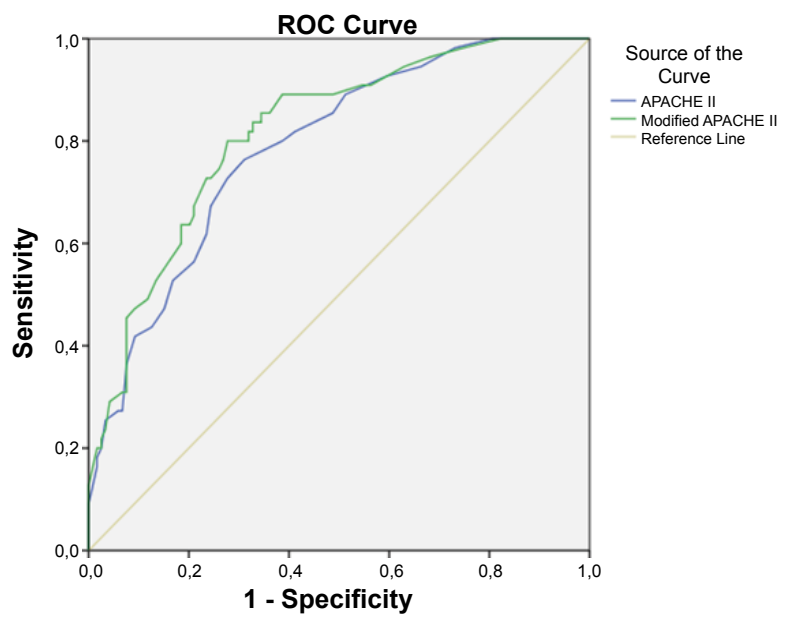

Figure 3: Receiver Operating Characteristics (ROC) curve for APACHE II.

Blue line - ROC curve for isolated APACHE II score (AUC 0.78 [CI95\%: 0.718-0.857]). Green line - ROC curve for the modified APACHE II score including COPD, and IMV (AUC 0.80 [CI95\%:0.730-0.868]). 
Table 2

Univariate analyses and final model of factors associated with hospital death not included in the SAPS 3 and APACHE II.

\begin{tabular}{|c|c|c|c|c|}
\hline \multirow{2}{*}{ Variable } & \multicolumn{2}{|c|}{ Univariate model } & \multicolumn{2}{|c|}{ Multivariate model } \\
\hline & OR (CI 95\%) & $\mathrm{p}$-value & OR (CI 95\%) & $\mathrm{p}$-value \\
\hline IMV & $6.48(3.14-13.40)$ & $<0.001$ & $3.83(1.49-9.83)$ & 0.005 \\
\hline Length of IMV & $1.13(1.06-1.21)$ & $<0.001$ & - & - \\
\hline TQT & $2.99(1.02-8.73)$ & 0.047 & - & - \\
\hline Length of TQT & $1.01(0.99-1.03)$ & 0.570 & - & - \\
\hline COPD & $3.31(0.71-15.33)$ & 0.126 & $6.82(1.22-38.18)$ & 0.029 \\
\hline Hypertension & $0.48(0.22-1.04)$ & 0.067 & - & - \\
\hline DM & $0.80(0.42-1.54)$ & 0.508 & - & - \\
\hline Smoking & $0.88(0.39-1.99)$ & 0.755 & - & - \\
\hline Alcoholism & $0.82(0.28-2.41)$ & 0.716 & - & - \\
\hline Hepatic Failure & $4.22(0.97-18.36)$ & 0.051 & - & - \\
\hline AKI & $3.16(1.55-6.44)$ & 0.002 & - & - \\
\hline Hyperglycemia & $0.77(0.40-1.49)$ & 0.439 & - & - \\
\hline Vasoactive agents & $2.55(1.31-4.98)$ & 0.005 & - & - \\
\hline $\mathrm{MAP}<70 \mathrm{mmHg}$ & $3.45(1.66-7.19)$ & $<0.001$ & $2.78(1.15-6.74)$ & 0.023 \\
\hline $\mathrm{RF}<25$ & $0.55(0.28-1.07)$ & 0.077 & & \\
\hline \multicolumn{5}{|l|}{$\mathrm{Na}$} \\
\hline$<130 \mathrm{mEg} / \mathrm{l}$ & $1.26(0.50-3.17)$ & & & \\
\hline $130-149 \mathrm{mEq} / \mathrm{l}$ & 1.0 (reference) & 0.057 & - & - \\
\hline$\geq 150 \mathrm{mEq} / \mathrm{l}$ & $5.37(1.28-22.55)$ & & & \\
\hline $\mathrm{K}$ & & & & - \\
\hline$<3.5 \mathrm{mEq} / \mathrm{l}$ & $1.00(0.42-2.39)$ & & & \\
\hline $3.5-5.4 \mathrm{mEq} / \mathrm{l}$ & 1.0 (reference) & 0.999 & - & - \\
\hline$\geq 5.5 \mathrm{mEq} / \mathrm{l}$ & $0.98(0.32-2.96)$ & & & \\
\hline $\mathrm{Ht}<30 \%$ & $1.95(1.00-2.78)$ & 0.046 & - & - \\
\hline Platelets < 100000 & $2.18(0.88-5.43)$ & 0.098 & & \\
\hline Total Bilirubin $<2 \mathrm{mg} / \mathrm{dL}$ & $0.25(0.08-0.74)$ & 0.011 & - & - \\
\hline $\mathrm{GCS} \leq 8$ & $2.77(1.33-5.77)$ & 0.007 & - & - \\
\hline ICU stay length & $1.06(1.01-1.10)$ & 0.008 & - & - \\
\hline SAPS 3 & - & - & $1.03(1.00-1.06)$ & 0.027 \\
\hline APACHE II & - & - & $1.08(1.02-1.14)$ & 0.027 \\
\hline
\end{tabular}

$\mathrm{IMV}=$ invasive mechanical ventilation; TQT = tracheostomy; COPD = chronic obstructive pulmonary disease; $\mathrm{DM}=$ diabetes mellitus; $\mathrm{MAP}=$ mean arterial pressure; $\mathrm{AKI}=$ acute kidney injury; GCS = Glasgow coma scale; RF = respiratory frequency; $\mathrm{Na}=$ serum sodium; $\mathrm{K}=$ serum potassium; $\mathrm{Ht}=$ hematocrit. $\dagger$ stress hyperglycemia.

\section{DISCUSSION}

Our findings suggest that the need for IMV, history of COPD and MAP below $70 \mathrm{mmHg}$ are important prognostic factors associated with hospital death in elderly patients admitted to ICU.

The SAPS 3 was associated with the need for IMV, history of COPD and MAP below $70 \mathrm{mmHg}$ demonstrated an improved predictive power in comparison with the data originally described in this score. This tendency was also verified for the association between APACHE II, the need for IMV and a history of COPD. There were no differences in the predictive power of these two models.

The need for IMV was independently associated with hospital mortality. These results are in 
accordance with previous findings ${ }^{13,20}$. Farfel et al. did not consider age as a factor associated with hospital mortality in the elderly with no need for $I^{2} V^{21}$. Silva et al. found that patients older than 65 years in the use of IMV presented a poor prognosis and reported a mortality rate three times higher in ICU, higher length of need for IMV and lower rates of extubating compared to younger patients with similar clinical conditions ${ }^{22}$. Mortality rates two years after ICU discharge in subjects aged 80 or more years with a history of need for IMV were higher in those with acute illness (78\%), admitted because of surgical urgencies $(46 \%)$ and elective admissions (35\%) 22 .

According to our results, COPD is also associated with hospital death in elderly individuals. This finding is in accordance with those reported by Teixeira et al. They observed that patients with history of COPD had a high mortality rate in ICU $(27 \%)$ and two years after hospital discharge $(68 \%)^{24}$. Ongel et al. recommend that cases with severe COPD and cardiac comorbidities might be carefully monitored in intensive care settings because of the elevated risk of mortality ${ }^{25}$.

Some recent studies reported that stress hyperglycemia was associated with worse outcomes in adults ${ }^{26}$ and elderly ${ }^{13,27}$ patients admitted to ICU. Despite that, our study did not assure this association. Gale et al ${ }^{28}$ described that the aggressive glycemic control in patients with stress hyperglycemia is associated with increased mortality. In our study, the correction of glycemic levels was not evaluated which might partially justify the absence of the association described in literature.

The association between AKI and ICU mortality is controversial. Some studies recognized a relationship between increased length of stay in ICU, mortality and $\mathrm{AKI}^{29}$. It also seems to predict hospital readmission in individuals discharged of ICU and is associated with a higher probability of death 30 days after discharge ${ }^{30}$. Nevertheless, other studies demonstrated that AKI is not associated with mortality in subjects admitted in ICU and higher creatinine levels are associated with lower mortality rates in hemodialytic patients ${ }^{31,32}$. This study did not observe any associations between mortality and AKI. It is plausible that the wide variability of criteria adopted to define
AKI is responsible for those divergences among the studies.

We were also unsuccessful to establish any relationship between need for vasoactive agents, level of consciousness, and mortality. According to the literature, vasoactive agents might predict mortality in patients aged 90 years or more ${ }^{27}$.

\section{Limitations}

Our study presented some limitations: It was performed just in one center, based on a convenience sample, standard treatment was defined according to the on-call physician's discretion. Also, some important variables were not possible to be included in the final model, such as oxygenation index ( $\mathrm{PaO} 2 / \mathrm{FiO} 2$ ratio) and drugs in use.

The study included high-risk post-op patients, which corresponded to $35.5 \%$ of the sample. Surgical patients tend to present higher rates of unfavorable outcomes, which may have played some influence in our results.

In the ICU where this study was performed, the mortality rate is under the regional mean, in some cases up to $50 \%$ lower.

\section{CONCLUSION}

The past of COPD, need for IMV during the admission and MAP $<70 \mathrm{mmHg}$ are associated with the APACHE II and SAPS3 scores to predict mortality in the elderly patients admitted in ICU.

\section{Disclosure}

The authors declare no conflict of interest. This study obtained no financial support. Partial results of this study were present at the VII Congresso Luso Brasileiro de Medicina Intensiva.

\section{REFERENCES}

1. Moitra VK, Guerra C, Linde-Zwirble WT, Wunsch H. Relationship Between ICU Length of Stay and Long-Term Mortality for Elderly ICU Survivors. Crit Care Med [Internet]. 2016 [cited 2018 Jan 25];44(4):655-62. 
2. Marik PE. Management of the Critically Ill Geriatric Patient. In: Surgical Intensive Care Medicine [Internet]. Cham: Springer International Publishing; 2016 [cited 2018 Jan 25]. p. 743-58. Available from: http://link. springer.com/10.1007/978-3-319-19668-8_54

3. Batista CC, Gattass CA, Calheiros TP, Moura RB. Avaliação prognóstica individual na UTI: é possível diferenciar insistência terapêutica de obstinação terapêutica? Rev Bras Ter Intensiva [Internet]. 2009 [cited 2018 Jan 25];21:247-54. Available.from: http://www.scielo.br/scielo.php?script=sci_ arttext\&pid =S0103-507X2009000300003\&lng =pt\&n$\mathrm{rm}=$ iso\&tlng $=\mathrm{pt}$

4. Knaus WA, Draper EA, Wagner DP, et al. APACHE II: a severity of disease classification system. Crit Care Med [Internet]. 1985 [cited 2018 Jan 25];13:818-29. Available from: http://www.ncbi.nlm.nih.gov/pubmed/3928249

5. Silva Junior JM, Malbouisson LMS, Nuevo HL, et al. Aplicabilidade do escore fisiológico agudo simplificado (SAPS 3) em hospitais brasileiros. Rev Bras Anestesiol [Internet]. 2010 [cited 2018 Jan 25];60:20-31. Available from: http://www.scielo.br/scielo.php?script=sci_ arttext\&pid $=$ S0034-70942010000100003\&Ing =pt\&n$\mathrm{rm}=\mathrm{iso} \& \mathrm{t}$ lng $=\mathrm{pt}$

6. Roberts GW, Quinn SJ, Valentine N, et al. Relative Hyperglycemia, a Marker of Critical Illness: Introducing the Stress Hyperglycemia Ratio. J Clin Endocrinol Metab [Internet]. 2015 [cited 2018 Jan 28];100:4490-7. Available from: https://academic.oup.com/jcem/article-lookup/doi/10.1210/jc.2015-2660

7. Level C, Tellier E, Dezou P, et al. Outcome of older persons admitted to intensive care unit, mortality, prognosis factors, dependency scores and ability trajectory within 1 year: a prospective cohort study. Aging Clin Exp Res [Internet]. 2017 [cited 2018 Jan 27];1-11. Available from: http://link.springer.com/10.1007/s40520-017-0871-z

8. Ge S, Nie S, Liu Z, et al. Epidemiology and outcomes of acute kidney injury in elderly chinese patients: a subgroup analysis from the EACH study. BMC Nephrol [Internet]. 2016 [cited 2018 Jan 26];17:136. Available from: http://www.ncbi.nlm.nih.gov/pubmed/27682843

9. Gong $Y$, Zhang $F$, Ding $F$, et al. Elderly patients with acute kidney injury (AKI): Clinical features and risk factors for mortality. Arch Gerontol Geriatr [Internet]. 2012 [cited 2018 Jan 26];54:e47-51. Available from: http://www. ncbi.nlm.nih.gov/pubmed/21684023

10. Xing $X-Z$, Wang $H-J$, Huang $C-L$, et al. Prognosis of patients with shock receiving vasopressors. World J Emerg Med [Internet]. 2013 [cited 2018 Jan 27];4:59-62. Available from: http://www.ncbi.nlm.nih.gov/pubmed/25215094

11. Vosylius S, Sipylaite J, Ivaskevicius J. Determinants of outcome in elderly patients admitted to the intensive care unit. Age Ageing [Internet]. 2005 [cited 2018 Jan 27];34:157-62. Available from: http://www.ncbi.nlm. nih.gov/pubmed/15713860

12. Goldstein R. Regression Methods in Biostatistics: Linear, Logistic, Survival and Repeated Measures Models. 2nd ed. McCulloch CE, Vittinghoff E, Shiboski SC, et al., editors. Vol. 48, Technometrics. 2006. 149-150 p.
13. Stein F de C, Barros RK, Feitosa FS, et al. Fatores prognósticos em pacientes idosos admitidos em unidade de terapia intensiva. Rev Bras Ter Intensiva [Internet]. 2009 [cited 2018 Jan 27];21:255-61. Available from: http://www.scielo.br/scielo.php?script=sci_arttext\&pid $=$ S0103-507X2009000300004\&Ing =pt\&n$\mathrm{rm}=\mathrm{iso} \& \mathrm{t}$ Ing $=\mathrm{pt}$

14. Said SMS El. Geriatrics intensive care unit: Outcome and risk factors for in hospital mortality. 2013 [cited 2018 Jan 27];2:166-9. Available from: http://dx.doi.org/ 10.4236/aar.2013.24024

15. García Acuña JM, Abu Assi E. Control de la glucemia en el paciente crítico. Rev Española Cardiol Supl [Internet]. 2015 [cited 2018 Jan 28];15:3-7. Available from: http:// linkinghub.elsevier.com/retrieve/pii/S1131358715300261

16. Metha RL, Kellum JA, Shah SV, et al. Acute Kidney Injury Network: report of an initiative to improve outcomes in acute kidney injury. Crit Care [Internet]. 2007; 11(2): R31. Available from: https://www.ncbi.nlm.nih.gov/ pmc/articles/PMC2206446/

17. McLernon S. The Glasgow Coma Scale 40 years on: a review of its practical use. $\mathrm{Br}$ J Neurosci Nurs [Internet]. 2014 [cited 2018 Jan 28];10:179-84. Available from: http://www.magonlinelibrary.com/doi/10.12968/ bjnn.2014.10.4.179

18. Mirza S, Clay RD, Koslow MA, et al. COPD Guidelines: A Review of the 2018 GOLD Report. Mayo Clin Proc [Internet]. 2018;93(10):1488-1502. Available from: https:// www.ncbi.nlm.nih.gov/pubmed/30286833

19. Lemeshow S, Hosmer DW. A review of goodness of fit statistics for use in the development of logistic regression models. Am J Epidemiol [Internet]. 1982 [cited 2018 Jan 28];115:92-106. Available from: http://www. ncbi.nlm.nih.gov/pubmed/7055134

20. Orsini J, Butala A, Salomon S, et al. Prognostic factors associated with adverse outcome among critically ill elderly patients admitted to the intensive care unit. Geriatr Gerontol Int [Internet]. 2015 [cited 2018 Jan 28];15:889-94. Available from: http://www.ncbi.nlm. nih.gov/pubmed/25255733

21. Farfel JM, Franca SA, Sitta M d. C, et al. Age, invasive ventilatory support and outcomes in elderly patients admitted to intensive care units. Age Ageing [Internet]. 2009 [cited 2018 Jan 28];38:515-20. Available from: http://www.ncbi.nlm.nih.gov/pubmed/19605608

22. Silva DV da, Ximenes GC, Silva Junior JM, et al. Aged patients with respiratory dysfunction: epidemiological profile and mortality risk factors. Rev Bras Ter Intensiva [Internet]. 2009 [cited 2018 Jan 28];21:262-3. Available from: http:// www.scielo.br/pdf/rbti/v21n3/en_a05v21n3.pdf

23. Tripp DG, Purdie G, Hicks P. Trends in the incidence of intensive care unit invasive mechanical ventilation and subsequent 2-year survival in very elderly New Zealanders. Intern Med J [Internet]. 2015 [cited 2018 Jan 28];45:80-5. Available from: http://doi.wiley.com/10.1111/imj.12630

24. Teixeira C, Cabral C da R, Hass JS, et al. Patients admitted to the ICU for acute exacerbation of COPD: two-year mortality and functional status. J Bras Pneumol [Internet]. 
[cited 2018 Jan 28];37:334-40. Available from: http:// www.ncbi.nlm.nih.gov/pubmed/21755188

25. Akkutuk E, Karakurt Z, Salturk C, et al. How do COPD comorbidities affect ICU outcomes? Int J Chron Obstruct Pulmon Dis [Internet]. 2014 [cited 2018 Jan 28];9:1187. Available from: http://www.dovepress.com/how-do-copd-comorbidities-affect-icu-outcomes-peer-reviewed-article-COPD

26. Todi S, Bhattacharya M. Glycemic variability and outcome in critically ill. Indian J Crit Care Med [Internet]. 2014 [cited 2018 Jan 28];18:285. Available from: http://www.ncbi.nlm.nih.gov/pubmed/24914256

27. Sim YS, Jung $H$, Shin TR, et al. Mortality and Outcomes in Very Elderly Patients 90 Years of Age or Older Admitted to the ICU. Respir Care [Internet]. 2015 [cited 2018 Jan 28];60:347-55. Available from: http://www.ncbi. nlm.nih.gov/pubmed/25406344

28. Gale SC, Sicoutris C, Reilly PM, et al. Poor glycemic control is associated with increased mortality in critically ill trauma patients. Am Surg [Internet]. 2007 [cited 2018 Feb 16];73:454-60. Available from: http://www.ingentaconnect. com/content/sesc/tas/ 2007/00000073/00000005/art00007
29. Wijewickrama ES, Ratnayake GM, Wikramaratne C, et al. Incidences and clinical outcomes of acute kidney injury in ICU: a prospective observational study in Sri Lanka. BMC Res Notes [Internet]. 2014 [cited 2018 Jan 28];7:305. Available from: http://www.ncbi.nlm.nih. gov/pubmed/24884808

30. Horkan CM, Purtle SW, Mendu ML, et al. The Association of Acute Kidney Injury in the Critically IIl and Postdischarge Outcomes. Crit Care Med [Internet]. 2015 [cited 2018 Jan 28];43:354-64. Available from: http://www. ncbi.nlm.nih.gov/pubmed/25474534

31. Miraoui W, Mebazaa M, Frikha N, et al. [Isolated acute renal failure is not associated to an increase in mortality of patients in intensive care units]. Tunis Med [Internet]. 2004 [cited 2018 Feb 16];82:996-1000. Available from: http://www.ncbi.nlm.nih.gov/pubmed/15822467

32. Herrera-Añazco $P$, Taype-Rondan A, Pacheco-Mendoza $\mathrm{J}$, et al. Factors associated with mortality in a population with acute kidney injury undergoing hemodialysis in Peru. ] Bras Nefrol [Internet]. 2017 [cited 2018 Feb 16];39:119-25. Available from: http://www.gnresearch.org/ doi/10.5935/0101-2800.20170029 